Alexis TROUDE, Ph.D. ${ }^{1}$

\title{
SERBIA, BETWEEN EAST AND WEST
}

https://doi.org/10.18485/iipe_balkans_rssc.2020.ch12

\begin{abstract}
Serbia, a country of 7 million inhabitants that experienced its rebirth in 2006 with the end of the State Union of Serbia and Montenegro, faces several challenges in 2020. Its Euro-Atlantic integration is progressing gradually, but not as fast as expected. Although the EU accession negotiations show strong cooperation between the Serbian government and the EU, integration into the $\mathrm{EU}$ will not take place until 2028. Moreover, official Serbia, still plagued by the 1999 bombings of the whole country, cannot impose the entry into the Atlantic Pact on a reluctant population. This situation places it in a difficult situation, with neighbours already (Bulgaria, Croatia, Hungary, Romania, and Montenegro) or in the process of entering NATO (North Macedonia quickly, Bosnia \& Herzegovina and Kosovo later). The neutrality policy pursued by the Serbian governments for several years has led it to rebalance the strong political and economic presence of the West. Relations with Russia are in full swing, with numerous military agreements and the revival of the Turkish Stream gas pipeline, but also through the Foreign Direct Investment (FDI) of Russian national companies in the field of transport and energy. China has become a major partner of Serbia, which is leading an all-around industrial and logistical geopolitics in Serbia; the Silk Road project places Serbia at the heart of the deployment of Chinese companies in Europe. Finally, Turkey, through numerous visits by Mr. Erdogan, has become a strong partner. With an important number of military and commercial agreements, Turkey is managing more than 800 societies. In this perspective of the reorientation of interests, what are its strategic interests?
\end{abstract}

Serbian diplomacy takes up the frameworks and orientations of the NonAlignment policy, which began at the time of the Cold War. The best example is the number of supports among emerging countries that it found in her ardent defence of Kosovo and Metohija within her territorial framework. More than $54 \%$ of humanity and all the greatest nations follow it in this policy: China, Russia, and Brazil. The great Muslim nations, more than half of African countries, and two-thirds of Asian

\footnotetext{
${ }^{1}$ Professor, The University of Versailles, Versailles, France.

E-mail: troudealexis@gmail.com.
} 
countries are in this global fight. In its immediate environment, active diplomacy of integration into old or new institutions seeks to overcome obstacles. In the face of the Albanian provocations and the blockages of Croatia in the process of Euro-Atlantic integration, Serbia has been able to play the card of geopolitical groupings in recent years. Placed as a 'Pole of stability' of the Balkans by some Western powers, it has developed a policy of peace and reconciliation (Bosnia-Herzegovina). From an economic point of view, it wants to be part of existing groups (Little Schengen) or new groups (Bosnia-Turkey-Serbia axis).

In this context, we must evaluate Serbia's position according to the following axioms:

- Will Serbia remain in touch with the Atlantic area (USA, Germany), or will it find its place among its traditional 'allies' (Russia, France)?

- In an increasingly multipolar world, will Serbia be able to use emerging countries (Turkey, Gulf countries) as levers of power?

- Are we really witnessing the emergence of a sustainable pole of stability around Serbia in Southeastern Europe?

Key words: EU, NATO, China, Russia, emerging countries, Non-aligned, neutrality, pole of stability

\section{SERBIA'S ACCESSION NEGOTIATIONS WITH THE EU PENDING}

Relations between Serbia and the European Union have experienced periods of closer relations, followed by periods of estrangement. The negotiations had begun well, with the opening in October 2005, at the same time as the negotiations for the EU antechamber for Bosnia and Herzegovina, known as the Stabilisation and Association Agreement. But they were suspended seven months later by the EU, which considered that Belgrade's cooperation with the ICTY was insufficient. Fortunately, the Stabilisation and Association Agreement was signed in April 2008, which came into force in September 2013 (Troude, 2015). Since then, difficult but serious negotiations have led to the opening of 18 out of 35 chapters. But Serbia's integration into the European Union was less and less supported by the population. While in 2015, there were still more than $65 \%$ of the citizens in favour of joining the EU as a symbol of economic prosperity, in July 2019, this number decreased to only $53 \% .^{2}$

\footnotetext{
${ }^{2}$ A public opinion poll conducted in July 2019 showed that Serbia's membership in the European Union would support 53 percent of Serbian citizens, according to the Ministry of European Integration (Za ulazak u EU, 2019).
} 
The regional context has indeed changed in the last fifteen years Serbia, despite economic difficulties, seems to be the safest country in an unstable environment. That is why the EU appointed it in 2015 the Balkan 'Pole of stability' amid the migration crisis. But there is still a major obstacle for Belgrade - the question of Kosovo. In 2013, the EU forced Belgrade to start a dialogue on an equal footing with what Serbia still considers its southern province, despite a proclamation of its independence in February 2008. In addition to these negotiations showing the uncompromising position of the Priština authorities, Belgrade will face a dilemma at the end of the process with Brussels. It will either sign Chapter 35, allowing it to close accession negotiations, but at the cost of losing sovereignty over its southern region, or it will preserve its territorial integrity by keeping its southern province in its lap and saying goodbye to the EU definitively.

The question today is the future of these discussions between Serbia and the EU. We remember the Croatian pressure on Serbia's accession negotiations in 2015-2016. After several months of intense pressure from Zagreb on Brussels, the stalling on the accession negotiations of Serbia had been lifted, but under very strict conditions. They implied full cooperation of Belgrade with the International Criminal Tribunal for the former Yugoslavia, reform of the status of minorities in Serbia, although already fairly well protected by a modern Constitution, and finally, in the words of the Croatian Foreign Minister, Serbia would have to guarantee legal protection to all victims for infringement of minority rights, which obviously included the right to damages.

On the other hand, every Serbian leader knows perfectly well that the last chapter will be the most difficult: it is a major obstacle to the recognition of Kosovo's independence. Finally, the EU is constantly pushing back Serbia's accession to the EU: after 2020 and then 2025 as the horizon, Jean Claude Juncker, President of the European Commission, declared at the beginning of July 2019 that accession is possible in 2028!

\section{A STILL SIGNIFICANT ROLE OF THE UNITED STATES AND NATO IN THE REGION}

After a foreign policy oriented towards China or Russia under S. Milošević, who fell from power in 2000, the leaders of the young Serbian democracy turned to the West. But this new orientation, apart from not being unanimous among the Serbian political world, is still struggling to move forward assertively. 
Yet who would have thought, after the NATO bombing in 1999, Serbia would work in joint operations with its soldiers? On 19 June 2003, the State Union of Serbia and Montenegro submitted a formal request to the NATO for admission to the Partnership for Peace. ${ }^{3}$ In the same year, it even sent a contingent of 200 soldiers to participate in NATO operations in Afghanistan. On 18 July 2005, Serbia and Montenegro signed an agreement with NATO authorizing the transit of the Atlantic armed forces throughout the territory of Serbia and the use of garrisons along the main roads. Six years after Operation Allied Force in 1999, the Serbian authorities seem to want to integrate the structure that had hit them hard, at all costs, even at the cost of limiting their sovereignty. But since this agreement, no progress has been observed. Serbian opinion is fiercely and overwhelmingly against membership, moreover, since 2012 and the arrival of the Serbian Progressive Party, a pro-Russian inflection has been perceptible. This is why the principle of 'neutrality' is set up as a real dogma in matters of national defence by the Serbian authorities. Even if it does not have an important role anymore, this leads the Serbian Army to perform joint exercises with NATO forces under American domination, as well as with Russian troops.

While more than $72 \%$ of the population would have voted against joining NATO, the United States has made the Belgrade government swallow a bitter pill. On 16 January 2015, Serbia signed an Individual Partnership Action Plan (IPAP) with NATO, the last step before final membership in the Alliance. But the IPAP stipulates the 'full use of the territory of Serbia' for manoeuvres and provides for the installation of military bases on its soil. It should be remembered that these conditions were considered unacceptable in February 1999 by Slobodan Milosevic and led to the NATO war against Serbia. ${ }^{4}$

We understand better today why, as of 8 June 1999, the troops of NATO intervened in Kosovo and Metohija, the southern province of Serbia. Since that date, Kosovo has been divided into five military zones under French, British, German, Italian, and American control (Marković, 2013). Near the largest US base in Europe (Camp Bondsteel), the Serbian authorities are building military base 'Jug' (South) in close collaboration with the Ohio

\footnotetext{
${ }^{3}$ The Republic of Serbia signed the Framework Document in Brussels on 14 December 2006, thereby officially became a participant in the Partnership for Peace.

${ }^{4}$ The intensive bombing between February and June 1999 resulted in more than 2,700 deaths, the majority of them civilians - and this was in contradiction with the rules of NATO, a defensive military alliance which then intervened outside its military zone.
} 
National Guard (U.S. Embassy in Serbia, 2019). Located in the military protection zone near Bujanovac, on the borders of Kosovo, it should serve as an anteroom for the Partnership for Peace. Indeed, the 'Jug' base is intended to be a training centre within the framework of the Partnership for Peace. But some would say that the 'Jug' base is the counterpart to the 'Russian-Serbian Humanitarian Center'. This Russian 'base' located near another city of Serbia, in Niš, has existed since 2012. Since it was planned for the assistance to the countries of the region in the event of natural disasters and emergencies, it is considered by the Americans at least as an advanced point of the Russian presence in their sphere of influence deployed in Serbia, reinforcing an already bloated Balkan system - four bases in Romania, two in Bulgaria and one in Bosnia and Herzegovina (Bilbija, 2015).

\section{THE GROWING INFLUENCE OF RUSSIA}

On 9 May 2015, 75 soldiers of the Serbian 'National Guard' paraded for the first time in their history on Red Square alongside the Russian Army on the occasion of the celebration of the 70th anniversary of the victory of the USSR over Nazi Germany. For US Senator Chris Murphy, the growing influence of Russia in Serbia has since posed a threat: 'Russia is marching on Serbia with more influence than ever... We need resources to implement a strategy' against Russia (Robinson, 2015).

Alexei Miller, in an interview given on 9 April 2015 to the Belgrade's newspaper 'Politika', said that Gazprom maintained the South Stream project, but only had to change its course in accordance with the decisions of the EU. Called the Turkish Stream, this pipeline will pass through Istanbul and Thessaloniki. Its $403 \mathrm{~km}$ section in Serbia was completed in December 2019. The European sanctions imposed on Russia have enabled Serbia to significantly increase sales of its agricultural products to Russia in 2014, and in turn for Russia to bypass the sanctions. But the EU has launched a real 'milk battle' as punishment. Since spring 2015, to make up for the deficits created by the sanctions against Russia, the EU has been pouring tonnes of low-cost milk into Bosnia and Herzegovina and Serbia. ${ }^{5}$

\footnotetext{
${ }^{5}$ This is how Serbia has become, in recent years, a land of predilection for 'land grabbing', especially in the rich agricultural region of Vojvodina, north of the Danube, where multinational agribusinesses are buying land and old agricultural combines, turning Serbia - whose agriculture is its great wealth - little by little into a supplier of raw materials but also into an outlet for EU agricultural surpluses.
} 
The return of the Russians to this energy race is striking. Since 2007, the Burgas (Bulgaria) - Alexandroupoli (Greece) pipeline has made it possible to avoid Turkey by passing through two Orthodox countries. But above all, the American gas pipeline project 'Nabucco', Istanbul-Vienna by Romania, is competing with the Russian gas pipeline project 'South Stream'. The latter would follow a much safer, and therefore less costly route, as it would pass through Bulgaria, Serbia and Croatia, with which agreements have already been concluded. In February 2007, Putin signed a comprehensive gas transit agreement with Croatia, a country that was not known for its inclination towards Russia, and in 2008 Gazprom merged with the Srbijagas - Gas Company and acquired the NIS oil tanker in Serbia (Troude, 2010).

The Renaissance of the East-West conflict in 2015 is obvious here. The South Stream project has died as a result of EU pressure on one of the newly acceded countries, Bulgaria, which declared in November 2014 that it no longer wanted the Russian gas pipeline. Putin then changed his mind and soon proposed the construction of the 'Turkish Stream', which would bring Russian natural gas from Turkey to Southern Europe. ${ }^{6}$

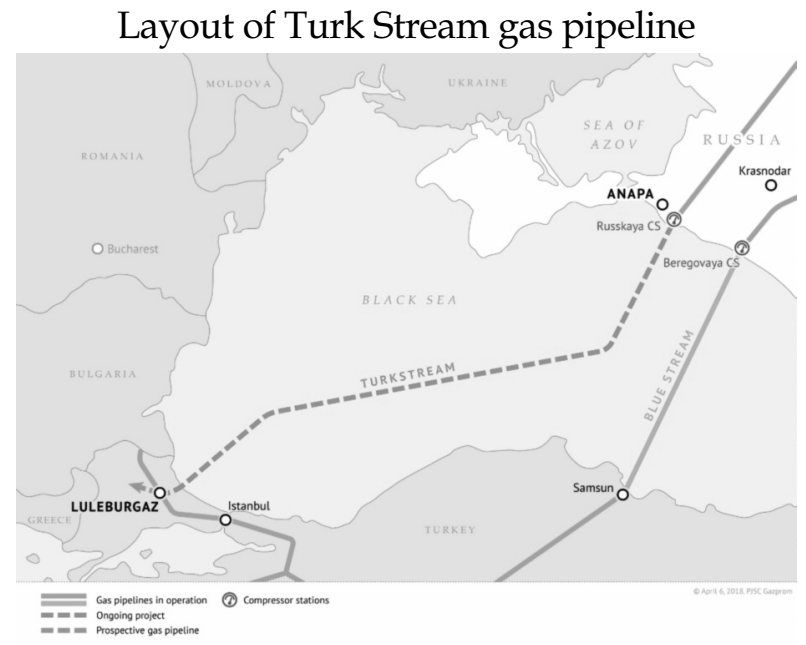

Source: Internet

\footnotetext{
${ }^{6}$ The Memorandum of Understanding for the construction of the Turkish Stream gas pipeline was signed by Gazprom and Botas in December 2014 (New gas pipeline towards Turkey, 2014).
} 
However, the EU is constantly putting pressure on the countries in Southeast Europe that should be involved in this project in order to prevent its construction. Proposal of a hypothetical 'Eastern Ring', blackmail on credits to Greece, and the other revamping of EU-US projects of the 1990s (TAP or TANAP) seem for the moment to dissuade Gazprom and the Russian government from starting major works (Troude, 2019, p. 134). Despite this, the Russian giant has managed to build more than 400 kilometres of gas pipelines across Serbia, completed in late 2019.

Since the Progressive Party of T. Nikolić came to power in 2012 and A. Vučić became president of Serbia in 2017, Serbian foreign policy has experienced a pro-Russian inflection. Frequent visits by heads of state to both countries show this: in January 2019, Putin received a triumphant welcome in Belgrade under the auspices of President Vučić, repeating the official visit with great fanfare under the Nikolić mandate. Vučić paid an official visit on 9 May 2018, the day of the commemoration of the victory against fascism.

Militarily, too, the past few years have been prolific for Serbian-Russian relations. The Serbian government is proud to have six MIG 29 since 2017, which places Serbia as the first air power on the Balkan chessboard. In the summer of 2019, Russia successfully hijacked the military blockade of the EU countries surrounding Serbia and brought in a brand-new column of armoured vehicles; the Serbian army is expected to have 30 of these vehicles and 30 T 72 tanks in the near future. Finally, on 13, 14 and 15 September 2019, the first major Serbian-Russian manoeuvres were successfully carried out, notably with the use of the S-400 missiles. ${ }^{7}$

\footnotetext{
${ }^{7}$ On 5 November 2019, the President of the Serbian government, M. Aleksandar Vučić, has decided to cancel the contract under negotiation with the Russian public company Almaz-Antey, specialized in the production of short to long-range air defense systems, in particular, the Pantsir S-1 systems (SA-22 Greyhound in NATO code) and S-400 Triomph (SA-21 Growler in NATO code) affected by the contract. The latter was launched at the end of the exercise 'Slavic Shield 2019' which took place between two stages: the first stage took place during September 2019 when the Serbian and Russian soldiers specialized in anti-aircraft defense participated in joint training at the Russian Aerospace Forces Training and Application Center (Воздушно-космические силы) and the second stage resulted in a 3-day full-scale exercise between 24 and 29 October 2019. According to the Russian agency InterTass, the cancellation of this contract is due to the American pressures accompanied by threats of sanctions which Serbia undergoes, through the American State Department and more particularly Matthew Palmer, the current special representative from the US Department of State for the Western Balkans Such a position of responsibility underlines the proximity of the former US Secretary of State, Victoria Nuland. Victoria Nuland is nothing less than the wife of Robert Kagan, leader of the American neo-conservatives, co-founder of the former think-tank Project for the New American Century, which brings together persons deeply anti-Russian.
} 
In the field of transport, Russian railways are making very rapid progress by electrifying the Belgrade-Budapest and Belgrade-Bar lines, thus making it possible to connect the Serbian capital more quickly to Central Europe and the Adriatic Sea.

\section{SERBIA, A TROJAN HORSE OF CHINA IN EUROPE?}

On 17 June 2016, Chinese President Xi Jinping made a historic visit to Serbia. He signed a number of commercial contracts, but also demonstrated China's choice towards Serbia as a platform for entry into Europe, within the framework of the China-CEEC platform. China, through thermal power plants, roads, steel factories and private companies, intends to transform Serbia into the centrepiece of its entry system in the EU.

The main focus of China's efforts is in the transportation sector. The Chinese have clearly understood the importance of roads in Southeastern Europe, whose control would allow them to extend their economic influence over the EU in the second phase. This presence is important because it lies at the heart of the pan-European network, i.e., at the northsouth intersection (Budapest-Thessaloniki) and the east-west axis (Constantza in the Black Sea - Rijeka in the Adriatic). A section of the highway between Szeged (Hungarian border) and Belgrade is under construction.

Chinese national companies have also started to build a part of the Belgrade - Banja Luka highway, on the east/west axis connecting Serbia to the borders of Croatia (therefore the EU) and Belgrade-Bar, in the north/south direction so between Serbia and the Montenegrin coast. After building the Pupin Bridge over the Danube River in Belgrade (Zemun), the Chinese have recently completed the construction of a new bridge over the Sava River, near the city of Obrenovac. In 2013, the Serbian and Hungarian governments announced the construction of a modern railway linking Belgrade with Budapest, which will be realized by Chinese loans and Chinese companies. In addition to the great economic satisfaction of the two sides, this also allows China to move closer to the European Union.

This heavy interference in Serbian transport is coupled with a recent but very intense investment effort in the industry. Chinese state-owned companies are accelerating their grip on the industrial fabric in the former Yugoslavia. In Serbia alone, Chinese investment represented more than $\$ 7$ billion at the end of 2018 . 
Chinese company China Machinery Engineering Corporation is currently involved in the modernization of one part of the Kostolac thermal power plant, and they are also involved in the construction of the new block B (Jelisavac Trošić et al., 2018, p. 23). In the spring of 2016, the Chinese authorities announced the construction of a Chinese auto parts factory in the Belgrade suburbs, and the purchase of the Smederevo steelworks factory for US\$ 51.8 million. The Chinese company HBIS thus holds the only steel complex in the country, perpetuating the maintenance of 5,000 jobs in a region heavily affected by unemployment (Zakić and Radišić, 2019, p. 45). Finally, in 2018, the Chinese group Zidjin bought the copper mining RTB Bor, one of the region's largest ones, thereby perpetuating 5,000 jobs in a poor region. Besides investing in the traditional sector, Chinese companies are taking a keen interest in investments in agriculture and alternative energy.

On the 'Silk Road', the energy and trade corridor between China and Western Europe, the nerve centre is in Budapest. But by betting on Serbia, like the bridge between Zemun and Borča on the Danube called the 'Friendship Bridge', China intends to make Serbia its Trojan Horse at the southern edge of the EU to export its products by land to the largest market in the world. As the Serbian Minister of Trade, Tourism and Telecommunications, said in spring 2019: 'We urgently need investment, China offers loans without any conditions, unlike the EU, and ensures rapid realization' (Čubrilo Filipović, 2019). On 21 September 2019, the President of the Republic of Serbia stated that he was satisfied that Serbia had signed a Strategic Partnership with China, and the fact that the relations between the two countries were at the highest historical level.

\section{SERBIA AS A FIELD OF CONQUEST OF THE NEW REGIONAL POWERS: THE ARAB EMIRATES AND TURKEY}

Another emerging power to place its pawns in Serbia is the United Arab Emirates, which thus deployed their grip on Belgrade in a few years through massive investments of their sovereign fund 'Eagle Hills'. One example of this is the pharaonic urban project, called 'Belgrade Waterfront', which aims to completely redevelop an abandoned area on the banks of the Sava. This project gives the Emirate full ownership of more than two million square meters in the heart of the Serbian capital.

After the acquisition of the national aviation company JAT in 2013 (transformed into 'Air Serbia' and became a simple Balkan platform of 
the global network 'Etihad') and the purchase of cereal lands in the north of the country, the marriage between Serbia and the Emirates seems to be a union for the sole benefit of the Arab nation, which uses Serbia as a Trojan horse in the European Union.

Even better, the Belgrade authorities also seem to be under the influence of consulting firms close to the Emirates. This is how Aleksandar Vučić recruited Tony Blair as a consultant, with the mission of bringing Serbia's standards in line with those of the European Union. However, the United Arab Emirates will pay the consulting fees... and the Tony Blair Associates (TBA) firm maintains close ties with this Gulf monarchy. The TBA will help the Serbian government implement austerity reforms in the so-called priority sectors - measures very similar to those currently imposed on Greece.

For several years, the Presidents of Serbia and Turkey have taken advantage of official visits at the highest level of the two Presidents. Multiple trade deals and technical military deals have helped boost Turkey's economic presence in Serbia. 'Bilateral relations between Serbia and Turkey are at the highest level in the history of relations between the two countries', Erdogan said during his latest official visit to Belgrade (Erdogan Vučiću, 2020). The result is impressive: while there were only 130 in 2015, there are 800 Turkish companies in Serbia in 2020, which employ 10,000 people. They are present in the textile, automotive, and banking sectors. The other development point for Turkey's efforts is infrastructure. In 2018, the Turkish government provided \$400 million worth of works. For example, the Belgrade-Sarajevo highway (with \$285 million investment), which will soon connect Serbia and Bosnia and Herzegovina, but also the 403-kilometre stretch through the Serbian territory of the Turkish Stream pipeline. During his last visit to Serbia in October 2019, Erdogan, accompanied by a strong delegation of Turkish business leaders, signed agreements with his Serbian counterpart for 17 projects worth $\$ 395$ million (Turske investicije u Srbiji, 2020).

\section{CONCLUSION}

The European Union seems to alternate with Serbia between confidence in its role as a pillar of the Western Balkans and distrust of a government considered nationalist and political practices tainted with corruption. Even if the image of Serbia is no longer that of the 1990s, this country, proud of its values and independence, seems to be the scratchy 
hair of Westerners in the region. Faced with this delay from the European authorities, the Eurasian and Middle Eastern geopolitics are advancing rapidly. They have not yet filled the level of investment of Western companies in the region, but by controlling a large part of the strategic sectors of transport, energy, industry and armaments, these emerging powers on the Balkan chessboard are quickly catching up to assert itself as Serbia's most loyal partners at the dawn of the 2020s.

\section{REFERENCES}

Bilbija, B. (2015, April 23). Hladni rat u Nišu zbog ruske baze [Cold War in Niš because of a Russian base]. Politika, retrieved from http:// www.politika.rs/sr/clanak/325434/Hladni-rat-u-Nisu-zbogruske-baze. Accessed 15 December 2019.

Čubrilo Filipović, M. (2019, April 18). Kineski put ka Evropi [Chinese breakthrough towards Europe], retrieved from https:/ /www.vreme. com/cms/view.php?id=1683397. Accessed 17 December 2019.

Erdogan Vučiću: Najviši stepen saradnje u istoriji [Erdoğan to Vučić: The Highest Level of Cooperation in History]. (2020, February 11), retrieved from http://www.politika.rs/scc/clanak/447682/ErdoganVucicu-Najvisi-stepen-saradnje-u-istoriji. Accessed 15 February 2020.

Jelisavac Trošić, S., Stojanović Višić, B. \& Petrović, V. (2018). New Opportunities for Further Improvement of Economic Cooperation between Serbia and China. The Review of International Affairs, LXIX (1169), pp. 21-35.

Marković, S. M. (2013, September 13). Amerikanci grade vojnu bazu na jugu Srbije [The Americans are building a military base in the south of Serbia], retrieved from http://www.vaseljenska.com/vesti/ amerikanci-grade-vojnu-bazu-na-jugu-srbije/. Accessed 28 June 2018.

New gas pipeline towards Turkey. (2014, December 2), retrieved from https://www.gazprom.com/press/news/2014/december/article208 505/. Accessed 17 December 2019.

Robinson, A. (2015, May 10). How Russia manage to be closer to Serbia, The Observer.

Troude, A. (2010). La Serbie à la croisée des chemins: corridors énergétiques, privatisations et guerre du gaz [Serbia at a Crossroads: Energy Corridors, Privatizations and the Gas War]. Revue Géographique de l'Est, 50 (1-2), pp.1-14. 
Troude, A. (2015). Les Balkans occidentaux: enjeux énergétiques et intégration euro-atlantique [The Western Balkans: energy challenges and Euro-Atlantic integration]. Diplomatie, 73, pp. 30-35.

Troude, A. (2019). The Geopolitical aspects of the 1999 NATO aggression against Yugoslavia, in: N. Vuković (Ed.), David vs. Goliath: NATO war against Yugoslavia and its implications (pp. 123-136). Belgrade: Institute of International Politics and Economics.

Turske investicije $\mathrm{u}$ Srbiji: Rast $\mathrm{u}$ turbulentnim vremenima [Turkish Investments in Serbia: Growth in Turbulent Times]. (2020, January 31), retrieved from https://novaekonomija.rs/vesti-iz-zemlje/turskeinvesticije-u-srbiji-rast-u-turbulentnim-vremenima. Accessed 15 February 2020.

U.S. Embassy in Serbia. (2019). Retrieved from https:/ / rs.usembassy.gov / our-relationship/ policy-history/us-country-relations/. Accessed 16 December 2019.

Za ulazak u EU 53 odsto građana Srbije [53\% of Serbian Citizens is for EU integration]. (2019, August 23), retrieved from https:/ / www.danas.rs /politika/za-ulazak-u-eu-53-odsto-gradjana-srbije/. Accessed 16 December 2019.

Zakić K. \& Radišić, B. (2019). Influence of the Belt and Road Initiative on Chinese Investments in Europe, Case study: Balkan Countries, in: L. Zuokui \& I. Lađevac (Eds.), The Cooperation between China and Balkan Countries under the 'Belt and Road' Initiative (pp. 27-53), Beijing: Chinese Academy for Social Science. 